\title{
CITAS BÍBLICAS LITERALES DE CERVANTES EN CASTELLANO
}

Tras varios artículos míos en esta Revista sobre la Biblia en Cervantes ${ }^{1}$, nos toca ahora ofrecer una selección de cuarenta y tres citas de este género. No me referiré a las citas literales en latín, que ya traté en número de veintidós. $\mathrm{Ni}$ tampoco expongo las múltiples alusiones o reminiscencias bíblicas (unas ciento ochenta y cinco), ni haré mención de los treinta y un personajes bíblicos que nombre nuestro autor.

Ejemplos de estas alusiones bíblicas serían: "Y así de poco dormir y de mucho leer se le secó el celebro» (Quij. I,2), inspiradas en los Hechos de los Apóstoles $(26,14)$ : «Festo dijo en alta Voz: Estás loco, Pablo, las muchas letras te sacan fuera de sentido» (Vg.: "Te han llevado a la locura»; la trad. de Scío: «ensandecesten).

"Así que somos ministros de Dios, y brazos por quien se ejecuta en ella la justicia», que hace alusión a las palabras de San Pablo: "Así, nos tenga el hombre como ministros de Cristo y dispensadores de los misterios de Dios" (I Cor. 4,1). Cervantes conoce la locura de Nabucodonosor, cuando dice: «Dudaban de la merced que Nuestro Señor le había hecho en volverle de bestia en hombre» (II,1). El hecho se cuenta en el libro del profeta $\mathrm{Da}$ niel: Nabucodonosor fue convertido en bestia como castigo divino

1 Cervantes y la Contrarreforma», en t. XXIV, 1986, pp. 221-227; «Refranes de origen bíblico en Cervantes», t. XXVII, 1989, pp. 45-77; «La Providencia divina en Cervantes», t. XXVIII, 1990, pp. 219-230; «Instituciones y costumbres eclesiásticas en Cervantes», t. XXIX, 1991, pp. 73-91; «Citas bíblicas de Cervantes en latín», t. XXXI, 1993, pp. 39-50. Ver también: «Cervantes al servicio de la Contrarreformaw, en ALCANTARA, n. 17, 1989, pp. 7-64. 
(Dan. 4,13), pero cumplidos los siete tiempos, se le devolvió la razón (Dan. 13,33).

En cuanto a los personajes bíblicos, el mayor elogio de D. Quijote es para San Pablo. El narrador resume el suceso de la caída de San Pablo del caballo, en el episodio de las imágenes (II,58). Tan pronto la vio el Caballero, exclama:

«Este fue el mayor enemigo que tuvo la Iglesia de Dios Nuestro Señor en su tiempo, y el mayor defensor suyo que tendrá jamás; caballero andante por la vida, y santo a pie quedo por la muerte, trabajador incansable en la viña del Señor, doctor de las gentes, a quien sirvieron de escuela los cielos y de catedrático y maestro que le enseñara el mismo Jesucristo» (Sobre este suceso ver: Hech. 9,1-30; 22,1-21; 26,1-23; I Tim. 2,7; Gal. 1,11; II Cor. 4,10-11, etc.).

Las citas, en su mayoría proceden de alguna versión de la Vulgata, como ocurre con las citas en latín (Ver mi art. t. XXXI, pp. 39-50). San Ignacio de Loyola, que propuso el orden de las disciplinas eclesiásticas, dispone que se use de modo constante la Sagrada Escritura. Sobre la Vulgata escribe:

«Pero las lenguas, si se aprenden, entre los fines que se pretenden sea uno (en quanto se pudiera) defender la traducción que tiene aprobada la Iglesia» ${ }^{2}$.

Las palabras incluidas en el paréntesis del texto original, fueron suprimidas por la primera Congregación General (Decr. 27), quizás porque la frase suponía una restricción del uso de la Vulgata, que es siempre obligatoria.

González de Amezúa, al defender la latinidad de Cervantes, sostiene que no pudo leer la Biblia en romance por la prohibición conciliar $^{3}$, pero no lo creo así según probé en mi art. arriba citado. Ni tampoco proceden de los sermones, de la liturgia o de libros de piedad, como asegura Hatzfeld ${ }^{4}$, cuestión a la que volveré en la conclusión.

En este artículo omito muchas citas de mi artículo sobre los refranes de origen bíblico, que son igualmente literales (ver t. XXVII, pp. 45-77). Tampoco repito los textos literales sobre la providencia divina (t. XXXVII, pp. 219-230). Paso, pues, a citar, con un breve comentario.

\footnotetext{
2 Const. cap. 6,4, en Ignacio de Loyola. Obras completas, a cargo de IPARRAGUIRRE-DALMASES, Madrid, BAC, 2." ed., p. 495.

3 Cervantes creador de la novela corta, Madrid, CSIC, 1956, t. I, p. 48.

4 El Quijote como obra de arte del lenguaje, Madrid, CSIC, 1960, pp. 145-146.
} 
1. "Porque quien se humilla, Dios lo ensalza" (I,11).

La Vulgata: "Qui se humiliat, exaltabitur» (El que se humilla será ensalzado) (Mt. 23,12; Lc. 14,11 y 18,14). Cervantes recoge sólo la primera parte del "logon" y omite: "Y quien se ensalza, será humillado".

En el Coloquio de los Perros Berganza dice:

"La humildad es basa y fundamento de todas las virtudes, y que sin ella no hay alguna que lo sea».

Esta teoría procede de Hugo de San Víctor, y es compartida por autores de la época, como Osuna que escribe: "El que allega virtudes sin humildad, lleva polvo al viento" y al fin exclama: « $\mathrm{OOh}$ humildad, virtud soberana, madre y minero de virtudes! ${ }^{5}$.

Don Quijote aconseja a Sancho: "Préciate más de ser humilde virtuoso que pecador soberbio» (II,42), y el Caballero proclama solemnemente:

«El principal asunto de mi profesión es perdonar a los humildes y castigar a los soberbios; quiero decir: acorrer a los miserables y destruir a los poderosos» (II,52).

Cervantes hace decir al Rufián Dichoso: «El corazón humillado,/ Dios jamás lo desprecia», que responde al Salmo 50,19.

El dicho aparece en los refraneros (ver mi art. cit. t. XXVII, pp. 55-56).

2. «Es tan piadoso [Dios] que hace salir el sol sobre los buenos y los malos, y llueve sobre los injustos y justos» $(\mathrm{I}, 18)$.

Es una traducción literal de la Vulgata: "Qui solem suum oriri facit super bonos et malos, et pluit super iustos et iniustos" (Mt. $5,45)$. Cervantes cambió el orden de "justos e injustos", pero conserva el detalle de "Su sol». El dicho, que lo repite en Persiles (III,XI), aparece en los refraneros (ver mi art. cit., pp. 56-57).

3. "Quien ama el peligro perece en él» $(\mathrm{I}, 20)$.

Es versión literal de la Vulgata: "Quia amat periculum in illo periribit» (Ecclo. 3,26).

El texto pertenece a un libro deuterocanónico, que no aceptan los judíos ni los protestantes, por lo que está tomado directamente de la Vulgata, única Biblia admitida por el Concilio Tridentino (ver mi art. "Cervantes y la Contrarreforma", t. XXIV, p. 227).

5 Tercer Abecedario Espiritual, ed. de M. Andrés, Madrid, BAC, 1972, pp. 545 y 551 respectivamente. 
4. "Diré que me cupo en suerte la mujer fuerte, de quien dijo el Sabio que ¿quién la hallará?» (I,33).

La Vulgata escribe: "Mulierem fortem quis inveniet» (« $\dot{i}$ Mujer fuerte quién la hallará?». Prov. 31,10).

En Pedro de Urdemalas, se dice de la Gitanilla:

«Aquesta es la mujer fuerte

que se busca en la Escriturax.

El texto griego de los LXX habla de «mujer varonil». El hebreo «jail» comprende la fuerza del cuerpo y del alma (virtudes, ley de Dios, gobierno de la familia). Cervantes sigue el concepto tradicional sobre el puesto de la mujer en el hogar, pues se trata de la prueba que anselmo puso a su mujer para estar seguro de su virtud. Los Santos Padres, por su parte, aplican la frase a la Iglesia o a la Virgen María.

5. "Esta es carne de mi carne y hueso de mis huesos» $(I, 33)$.

Las palabras son de Adán: Y así como Adán despertó y la miró dijo: "Esta sí que es hueso de mis huesos y carne de mi carne" (Gen. 2,23). Cervantes invierte el orden, quizás porque cita de memoria, aunque no se debe a oídas de sermones, porque se inserta en un párrafo largo con varias citas sobre la creación del hombre y de la mujer, y de su unión conyugal:

«Cuando Dios crí́ a nuestro primer padre Adán en el Paraíso terrenal, dice la divina Escritura que infundió Dios sueño en Adán, y que, estando durmiendo, le sacó una costilla del lado siniestro, de la cual formó a nuestra madre Eva, y así como Adán despertó y la miró, dijo: $\propto$ Esta es carne de mi carne y hueso de mis huesos», y dijo Dios: «Por ésta dejará el hombre a su padre y a su madre y serán dos en una carne mesmax. $Y$ entonces fue instituido el divino sacramento del matrimonio, con tales lazos que sola la muerte puede desatarlos. Y tiene una fuerza y virtud este milagroso sacramento que dos diferentes personas sean una mesma carne» $(\mathrm{I}, 33)$.

Son palabras de Lotario a su amigo Anselmo, quien dejó a Camila en sus manos para probar la virtud conyugal. Lotario intenta persuadirle que no se puede poner a la mujer en situación de pecado, porque como los dos esposos son una misma carne, las manchas de ella afectan también a su marido. Cervantes sigue el segundo relato de la creación, parafraseando la formación del hombre y de la primera mujer, la institución del matrimonio y su indisolubilidad, según la doctrina católica, bíblica y tradicional.

Jesucristo citó estas palabras del Génesis con el mismo fin (Mt. 19,1-9), al igual que San Pablo (Ef. 5,12-33). Por su parte, el 
Concilio de Trento utiliza los mismos textos en la sesión del matrimonio ${ }^{6}$, de donde bebe Cervantes.

En el texto, antes transcrito, se insertan dos citas tomadas literalmente del Génesis. La doctrina es muy querida por Cervantes, pues la repite en otras ocasiones (ver n. 20, más abajo).

6. "Y dijo Dios: "Por ésta dejará el hombre a su padre y a su madre y serán dos en una carne mesma"” (I,33).

Es una cita contenida en el pasaje citado en la página anterior, encaminada también a probar la indisolubilidad del matrimonio. Jesús se dirige al mismo Génesis para dejar claro el designio del Creador sobre el carácter absoluto e indisoluble del matrimonio, que vuelve a repetir Cervantes (núm. 20).

Mientras el texto original dice "por esto" (por esta razón), Cervantes escribe "por ésta", o sea por la mujer. Se sigue a la Vulgata, pero el autor omite una frase intercalada: «Et adherebit uxori suae» («Y se unirá a su mujer»).

7. "Y el demonio... que se transforma en ángel de luz..." $(I, 33)$.

El texto se repite en varios lugares, donde Cervantes diserta sobre diversos aspectos del demonio (I,31; I,41; I,45; II,22; II,25; II,27; Persiles II, V, etc.), como si se uniera a la angustia medieval sobre el demonio ?.

Cervantes ve a Dulcinea encantada y convertida «de ángel en diablo" y de "luz en tinieblas». Lotario usa el mismo artificio del demonio, que engaña transformándose en ángel de luz, "siendo él de tinieblas». El Persiles dice de Auristela enferma "Viendo también que el ángel de luz de Auristela se había vuelto al de las tinieblas..." (IV.IX).

Los textos se refieren a San Pablo:

«Ipse Satanas transfigurat se in angelum lucis» (II Cor. 11,14). («El mismo Satanás se transforma en ángel de luz».

8. «Gloria sea en las alturas, y paz en la tierra a los hombres de buena voluntad» $(I, 37)$.

- I. LOPez de Ayala, El Sacrosanto y Ecuménico Concilio de Trento traducido al castellano, Paris, Libr. Rosa y Bouret, 1857, pp. 300-302.

7 Ver mi libro Las fuentes Bíblicas, Patrísticas y Judaicas del "Libro de Alexandre". Las Palmas, el autor, 1994, pp. 69-72. Y A. MONTE, «Un volto de l'angoscia medievale: il diavolo», en $F R$, I, 1954, pp. 1-16. 
Cervantes relata las buenas nuevas que trajeron los ángeles «la noche que fue nuestro día». El texto sigue literalmente a la Vulgata, que se aparta del texto original:

«Gloria in altissimis Deo et in terra pax hominibus bonae voluntatis» (Lc. 2,24).

mientras el texto original dice:

"Gloria a Dios en las alturas, y en la tierra paz a los hombres en quien él se complacen (B. Jer.), o «...en la tierra paz, buena voluntad para con los hombres» (Casiodoro de la Reina).

9. "Paz a esta casa» $(I, 37)$.

El texto se refiere al consejo del Maestro a sus discípulos para cuando entren en una casa: "Pax huic domi» (Lc. 10,15).

No tiene, pues, razón Hatzfeld al sostener que tanto la frase del núm. 8, como ésta y la que sigue en el núm. 10, son reminiscencias de la Liturgia y no citas de la Biblia (o.c., p. 145). Cervantes, precisamente, consigna el lugar y la situación evangélica. En alguna ocasión pueden ser recuerdos de oídas, pero no aquí, aunque nuestro autor las hubiese escuchado muchas veces al llevar el viático a un moribundo, donde el Ritual elige el consejo del Señor para saludar a la casa en que se entra.

10. "Y otras muchas veces les dijo: "Mi paz os doy, mi paz os dejo, paz a vosotros"” (I,37).

La Vulgata, en efecto, escribe:

«Pacem meam relinquo vobis, pacem meam do vobis» $(\mathrm{Jn} .14,27)$

«Pax vobis» (Jn. 20,19).

$\mathrm{El}$ "muchas veces» de Cervantes es un poco exagerado en relación con las veces que tales saludos aparecen en el Evangelio. La primera frase consignada, sólo una vez. "Pax vobis», tres veces [Jn 20,19 (=Lc. 24,36); Jn. 20,21; Jn. 16,23]. Esto no quiere decir que Jesús no las dijera "muchas veces", pues era el saludo propio del Señor y común a todas las gentes.

Los textos 8,9 y 10, son pruebas que Cervantes señala para defender su aserto: "La paz es el mayor bien que los hombres pueden desear en esta vida” $(I, 37)$, aunque él probablemente se refiera a los que usan las armas para alcanzar la paz.

La paz bíblica es de otro género. El "Shalom» hebreo no es un saludo banal, sino el deseo de que el individuo o la comunidad esté 
sana material y espiritualmente. Por eso "la paz sea con vosotros" equivale a "Dios esté con vosotros". Este es el sentido de Cristo: él la da no como la da el mundo. Cervantes parece indicar indirectamente este sentido, cuando concluye el texto: "Joya, que sin ella, en la tierra ni en el cielo puede haber bien alguno».

11. "Y el agradecimiento que sólo consiste en el deseo es cosa muerta, como muerta es la fe sin obras" $(\mathrm{I}, 50)$.

Cervantes hace una comparación utilizando la frase del apóstol Santiago:

«Sicut enim corpus sine spiritu mortuum est, ita et fides sine operibus mortua est» (Sant. 2,26).

Cervantes acomoda el mismo texto de la fe muerta, al agradecimiento, mientras Santiago lo refiere al cuerpo sin espíritu.

El texto apostólico obsesiona a Cervantes, según se aprecia por el número de veces que aparece en sus obras, desde La Galatea hasta el Persiles:

«Que mi fe nunca fue muerta, pues se avviva con mis obras» (Gal. lib. VI).

«Es fe muerta la que con obras no se manifiesta» (Gal. lib. III).

«Cada uno es hijo de sus obras» (Quij. I,47).

«Con las obras y la fe

hoy para el cielo se embarca

en mejor jarcida barca

que la que libró a Noé» (Poesía I a la toma de hábito de P. Padilla).

«No es posible ir al cielo sin buenas obras» (Ilustre fregona).

«Obras tales nunca las deja el cielo sin buena paga, como, a las que son malas, sin castigo» (Persiles, II,XIV).

La enseñanza bíblica entró en el ambiente teológico del s. XVI, llegando a ser una contraseña del pensar tridentino, contra los protestantes. El mismo Guzmán de Alfarache, se mueve en este sentido: "Siempre manifestó su fe con obras para que no se la considerasen por muerta» (I pt., lib. I, cap. 2).

Cervantes parece citar implícitamente el Decreto de Justificación del Concilio de Trento (Ayala, pp. 61-66 y 70-73), en el sentido de que la fe es el comienzo de la salvación por las obras:

«Si fe recobras / yo haré que te sobren obras» (Rufián dichoso, j. II).

Cervantes sigue el espíritu de los escritores de la época. Fray Luis de Granada escribe sobre el tema: 
« La fe que no está aneja a la caridad, y acompañada con buenas obras, y fortalecida con la obediencia de los santísimos mandamientos, esta fe es muerta y a nadie puede hacer justo, como dice el Apóstol Santiago» (Compendio de la Doctr. Crist.) ${ }^{8}$.

La «fe sin obras», como única que puede salvar es el campo de batalla del Protestantismo. Desde el prólogo que hizo en latín a sus obras completas, (1545) hasta sus últimos escritos, Lutero repite constantemente que no nos justificamos por las obras, sino por la sola fe en Cristo. Incluso confiesa que añadió "allein" (solamente) al texto paulino, porque se deduce del contexto: "Porque pensamos que el hombre es justificado [sólo] por la fe, sin las obras de la ley" (Rom. 3,28). Esto lo hace en 1530, en la Misiva sobre el arte de traducri ${ }^{9}$. En la misma obra llama a la carta de Santiago "epístola de herejes" por haber dado cabida a las obras. En la Controversia de Heidelberg (1518), cuando aún era católico, habla de la fe muerta, pero no cita a Santiago. Su pensamiento, repartido por todas sus obras, se puede resumir en esta frase: "Hay que advertir muy bien y tener en cuenta que sólo la fe, sin obras, santifica, libera y salva, como repetiré más veces en lo sucesivo" (La Libertad del Cristiano, 1520, o.c., p. 159).

12. "Acerca del poder de Dios ninguna cosa es imposible" (II,1). Son palabras del licenciado loco, que se curó por la misericordia de Dios. Cervantes aplica el texto a esta situación, mientras que la Biblia se refiere a otro hecho portentoso: la concepción del hijo de Dios en el seno de María sin obra de varón. Dios es omnipotente, y esta virtud divina se muestra en los prodigios de la historia de la salvación y en el poder taumatúrgico de Jesús.

La Vulgata escribe:

«Quia non erit impossibile apud Deum omne verbum» (Lc. 1,37). («Porque no hay cosa alguna imposible para Dios»).

Este poder de Dios se aplica también al portento de la concepción de Sara en su vejez: "¿Acaso hay algo imposible para Dios?» (Gen. 18,14). Ante la dificultad de que los ricos se salven, Jesús establece este principio: «Para los hombres eso es imposible, mas para Dios todo es posible» (Mt. 19,26).

- Fray Luis de Granada, Obra selecta, a cargo de A. Trancho y D. Díez, Madrid, BAC, parte I, cap. 3, p. 316.

- Cito por la ed. de TeOfanes Egido, Lutero: Obras, Salamanca, ed. Sígueme, 1977, pp. 313-314. 
13. "Y sé que la senda de la virtud es muy estrecha, y el camino del vicio, ancho y espacioso" (II,6).

Don Quijote diserta sobre las dificultades de la caballería andante. El vicio, ancho y dilatado camino, acaba en muerte, y el de la virtud, angosto y trabajoso, acaba en vida, y no en vida que se acaba, sino en la que no tendrá fin.

Estas declaraciones de don Quijote dan al texto el sentido moral del Evangelio, de donde procede:

«Entrad por la puerta estrecha: porque ancha es la puerta y espacioso el camino, que lleva a la perdición, y muchos son los que entran por él. ¡Qué angosta es la puerta, y qué estrecho el camino que lleva a la vida: y pocos son los que atinan con él!» (Mt. 7,13-14). gares:

La idea le ha gustado a Cervantes, pues la repite en varios lu-

«La senda de mi bien hállola estrecha;

la de mi mal tan ancha y espaciosa

cual de mi desventura ha sido hecha» (La Galatea, lib. III).

«El engañoso amor nos muestra

una senda por do entremos,

al parecer ancha y espaciosa” (Gal. lib. IV).

El texto transcrito arriba se relaciona con estas otras palabras de don Quijote:

«Unos van por el ancho camino de la soberbia... pero yo... voy por la angosta senda de la caballería” (II,32).

Más lugares reflejan el amor de Cervantes por la idea: Roberto habla de un mancebo al que educaba en La Gran Sultana:

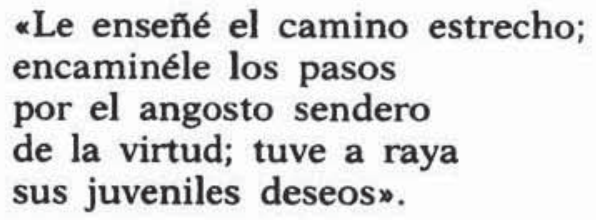

El P. Cruz comenta la dura vida religiosa de penitencia en $R u$ fián dichoso:

«Senda estrecha que la cruz señala / y forma» (Jorn. II).

Cervantes utiliza sólo las imágenes de "camino» y "senda», abandonando la metáfora evangélica de la "puerta». Las dos son usadas constantemente en el texto sagrado desde el Génesis hasta el Apocalipsis. 
Este tema era muy corriente en la España medieval, renacentista y barroca. Muchos refranes lo atestiguan:

«Muy angosto es el camino del cielo y muy ancho el del infiernon.

«Muy angosto es el camino por donde hay que ir al cielo».

«No se va al cielo por lo ancho y cantando, sino por lo estrecho y jadeandon.

14. "De la abundancia del corazón habla la lengua» (II,12).

La Vulgata lee: «Ex abundantia enim cordis os loquitur» (Mt. 12,34 y Lc. 6,45). Aquí el corazón no tiene el sentido de afectividad o amor, sino que el término hebreo posee un contenido más amplio: lo íntimo o interior del hombre, los sentimientos, los razonamientos, los pensamientos, los proyectos, etc.

La frase aparece en los refraneros españoles. Ya lo traté con sus variantes en mi art. cit., p. 49.

15. «En verdad que comemos el pan en el sudor de nuestros rostros" (II,13).

Referencia a la Vulgata: «In sudore vultus tui vesceris pane» (Gen. 3,19).

Cervantes expone que estas palabras son «la maldición que echó Dios a nuestros padres", refiriéndose a la vida trabajosa de los caballeros andantes.

El autor entiende el texto al modo tradicional y popular, pues el trabajo no es un castigo divino por el pecado, ya que antes de él Dios puso a la primera pareja en el Edén para que lo cultivara (Gen. 2,15). El trabajo duro es necesario para domar la naturaleza que se nos resiste y para continuar la acción creadora de Dios.

16. «Si el ciego guía a otro ciego, ambos van a peligro de caer en el hoyo» (II,13).

Cita literalmente la Vulgata:

«Caecus autem si caeco ducatum praestat, ambo in foveam cadunt» (Mt. 15,14).

La frase aparece también en los refraneros (ver el núm. 4 de mi art. citado). Cervantes lo pudo tomar del dicho popular, del Evangelio, del Arcipreste de Hita (c. 1145), de los Proverbios de Salomón, o del Calila e Dimna, lugares en que aparece el apólogo. La fuente 
del Calila y del Evangelio debe ser la misma: cuentos orientales que se hicieron famosos ${ }^{10}$.

17. "¡Oh hombre de poca fe!» (II,17).

Son palabras de don Quijote ante el miedo del carretero a los leones sueltos. Se acomodan a este hecho las mismas palabras que Jesús dijo a Pedro, cuando éste se hundía en el agua: «Modicae fidei, quare dubitasti?» (Mt. 14,31) («Hombre de poca fe ¿por qué dudaste?».

La cita está bien traída en un caso de miedo, al igual que en el Evangelio.

18. "Siendo el principio de la sabiduría el temor de Dios (II,20). Vulgata:

"Timor Domini principium sapientiae» (Prov. 1,7).

«Initium sapientiae timor Domini» (Ecclo. 1,14).

Este proverbio es muy corriente en la Biblia (Ps. 111,10; Job. 28,28; Ecclo. 1,20; Prov. 1,8; 9,10; 15,33, etc.).

En el Libro Sagrado se observa una evolución del «temor de Dios" hasta llegar al sentido ético de los Libros Sapienciales y del Evangelio. El sentido, pues, equivale a guardar los mandamientos. Así, "temeroso de Dios" (Act. 10,2.22; 13,16.26) es lo mismo que «hombre justo».

En otro lugar don Quijote une el temor de Dios con la «sabiduría», en la mejor línea de los Libros Sapienciales bíblicos:

«Primeramente, ¡oh hijo!, has de temer a Dios, porque en el temerle está la sabiduría, y siendo sabio no podrás errar en nada” $(\mathrm{II}, 42)$.

De este modo, Sancho sabrá gobernar, y no temerá más a un lagarto que a Dios.

10 Calila e Dimna: «Et el ome más culpado es fazer las malas obras et dexar así como si dos omes fuese que sirviesen el uno al otro et fuese el uno çiego et cayesen amos a dos en el foyo, que más culpa avría el que tenía ojos que non el çiego en caer» (ed. de CACHo Blecua y M.* Jesús LACARRA, Madrid, Castalia, 1984, p. 94).

Conde Lucanor: ${ }^{\mathrm{El}}$ desque llegaron a los lugares fuertes et peligrosos cayó el çiego que guiava al otro, et non dex 6 por esso de caer el çiego que reçelava el camino» (ed. de M. BlecuA, Madrid, Castalia, 1969, p. 186). 
19. «...palabras ociosas, de que nos han de pedir cuentas en la otra vida» (II,20).

Vulgata: "Omne verbum otiosum quod locuti fuerint homines, reddent rationem de eo in die judicii" (Mt. 12,36). ("Y dígoos que toda palabra ociosa que hablaren los hombres, darán cuenta de ella en el día del juicion).

Cervantes alude a las palabras bíblicas en boca de Sancho, que se queja contra don Quijote de tantos consejos, y que se meta a juzgar los temores o valentías ajenas; él prefiere "despabilar la espuma" en las bodas de Camacho a palabras ociosas.

Según San Jerónimo "palabra ociosa" es la que ningún provecho saca el que las dice, ni el que las oye. Pero la Biblia de Jerusalén, en nota al texto de Mateo, opina que no se trata de "ociosa" puramente, sino de palabra desprovista de fundamento, o calumnia, según el contexto contra los fariseos.

20. "A los dos que Dios junta no podrá separar el hombre» (II,21).

Vulgata: "Quod ergo Deus coniunxit, homo non separet» (Mt. 19,6). La palabra "dos" que no aparece en este texto, procede del versículo anterior: "Así que ya no son dos sino una sola carne".

Jesús utiliza una cita del Génesis $(2,24)$ y se encaminan a porbar el origen divino del matrimonio y su indisolubilidad (véase el $\mathrm{n} .5$ y 6 de estas citas).

21. "La mujer honrada bien puede llamarse "corona de su marido" " (II,22).

Vulgata: "Mulier diligens corona est viro suo" (Prov. 12,4). "La mujer virtuosa es corona de su marido").

Los Libros Sapienciales abundan en los valores de la mujer honrada, virtuosa y diligente. Al final del Libro de los Proverbios, el autor compuso un precioso canto a la perfecta casada, donde Fray Luis y Cervantes se han inspirado en numerosas ocasiones.

22. "A sólo Dios está reservado conocer los tiempos y los momentos» (II,25).

Vulgata: "Non est vestrum nosse tempora et momenta" (Act. 1,7). ( «No os toca saber a vosotros los tiempos y los momentos").

Cervantes se aprovecha del texto para probar que el mono y el diablo sólo hablan de cosas pasadas o presentes, pero nunca de las 
que están por venir; no son adivinos, sólo dios sabe los tiempos y los momentos.

El texto de Los Hechos de los Apóstoles responde a una pregunta de los discípulos sobre el tiempo de la venida del Reino de Dios (el fin del mundo según la concepción judía). Nadie sabe el día ni la hora, ni los ángeles, ni el Hijo; es materia que se ha reservado el Padre (Mt. 24,36).

Cervantes no pudo tomar esta cita de Casiodoro o Valera, que traducen: «Los tiempos y las sazones».

23. "Hagamos bien a nuestros enemigos, y que amemos a los que nos aborrecen" (II,27).

Esta frase es la traducción del mismo texto que escribió en latín en el Prólogo de la I. ${ }^{a}$ parte, aunque aquí añade la segunda parte del versículo. El texto de la Vulgata es:

«Diligite inimicos vestros, benefacite qui oderunt vos» (Mt. 5,44; Lc. 6,27 ).

Este mandamiento preocupa a Cervantes, pues, de nuevo hace reflexionar a Cide Hamete sobre la muerte de don Quijote:

«Y con esto cumplirás tu fe cristiana, aconsejando bien al que mal te quiere» $(\mathrm{II}, 74)$.

No obstante, nuestro autor, dice que aparentemente es difícil de cumplir, pero no lo es sino para aquellos que tienen menos de Dios que del mundo, o más carne que espíritu (II,27).

24. "Dijo [Jesús] que su yugo era suave y su carga liviana" (II,27).

Vulgata: «Iugum meum suave est et onus meum leve» (Mt. 11,30).

Cervantes utiliza las palabras de Jesús para probar que el mandamiento de amar a los enemigos no es tan difícil, pues él no pondría nunca un precepto que fuese imposible de cumplir. La ley de Jesús se contrapone a la ley mosaica que contenía preceptos insoportables (Hech. 15,10; Gal. 5,1).

En La Galatea acomoda Cervantes este "yugo" al matrimonio, recordando el rito católico:

«A llevar este yugo como debe,

que, aunque parece carga, es carga leve» (lib. III). 
25. "Tened todas las cosas como si no las tuviésedes" $(\mathrm{II}, 44)$.

Vulgata: "Qui emunt tanquam non possidentes, et qui utuntur hoc mundo tanquam non utunturn (I Cor. 7,30-31).

San Pablo se refiere a la disponibilidad interior del cristiano ante la brevedad del tiempo. El que sigue a Cristo debe ser libre de las cosas de este mundo, porque todo pasa:

«El tiempo es corto: lo que resta es que los que tienen mujeres, sea como si no las tuviesen, y los que lloran, como si no llorasen, y los que se alegran, como si no se alegrasen; y los que compran, como si no poseyesen, y los que usan de este mundo, como si no usasen, pues pasa la figura de este mundo» (Scio).

El griego «ós me katajrómenoi" parece indicar el mal uso o abuso de las cosas.

Cervantes pone el texto en la boca del moro Benengeli, que hace elogios de la pobreza e indigencia de don Quijote. No se trata de una pobreza normal, sino extrema, como lo dijo "uno de los mayores santos" (San Pablo). El mismo autor la define como "pobreza de espíritu», refiriéndose a San Mateo: "Bienaventurados los pobres de espíritu" (Mt. 5,3).

En la Biblia los "pobres de Yahveh" o "pobres de espíritu", son los que tienen el alma libre y dispuesta para Dios, y tienen conciencia de su miseria personal necesitando el auxilio divino. La pobreza real, de la que tanto habló Jesucristo, es una disposición para esta otra.

26. «El cual del estiércol sabe levantar los pobres» (II,51). Vulgata:

"Suscitans a terra inopem, et de stercore erigens pauperem» (Ps. 112,7). («El levanta del polvo al hombre, y del estiércol al pobre»).

Otro texto bíblico repite la idea:

«Alza del polvo al humilde, alza del muladar al indigente para hacerle sentar junto a los nobles y darle en heredad trono de gloria» (I Sam. 2,8).

Don Quijote escribe a Sancho, gobernador de la f́nsula Barataria, y da gracias al cielo por las noticias que tiene de su discreción y cordura. Así, Dios ha levantado al pobre y humilde Sancho del estiércol, del muladar, y de tonto lo ha hecho discreto, para el buen gobernar. Cervantes muestra, una vez más, su espíritu crítico contra los ricos y poderosos de este mundo, que rigen peor la nación que un ignorante. 
La idea se relaciona también con el canto de María: «Derribó a los potentes de su trono y exaltó a los humildes. A los hambrientos colmó de bienes y despidió a los ricos sin nada» (Lc. 1,52-53).

\section{7. «El cielo padece fuerza» (II,58).}

Don Quijote discurre sobre los santos, después de haber visto las imágenes que unos labradores llevaban envueltas en sábanas. Manifiesta que los santos profesaron lo que él profesa, pero con una gran diferencia: ellos fueron santos y pelearon a lo divino; don Quijote, como pecador, pelea a lo humano, y a continuación exclama:

«Ellos conquistaron el cielo a fuerza de brazos, porque el cielo padece fuerza, y yo hasta agora no sé lo que conquisto a fuerza de mis trabajos».

El sentido bíblico de este pasaje es discutido. San Mateo escribe:

«Desde los días de Juan el Bautista hasta ahora, el Reino de los Cielos sufre violencia, y los violentos lo arrebatan» $(11,12)$.

La Vulgata escribe: «usque nunc regnum caelorum vim patitur, et violenti rapiunt illud". El original griego utiliza el verbo «biadsetai» ( $\beta \iota \alpha ́(\varepsilon \tau \alpha \iota)$, traducido por la Vg. "vim patitur». Se duda si el tiempo es medio o pasivo. El medio hay que eliminarlo, porque exigiría un complemento, como el texto paralelo de Lucas: "Y todos se esfuerzan con violencia para entrar en él» ( $\propto \mathrm{Et}$ omnis in illud vim patitur», Lc. 16,16). La traducción sería: «Cada cual se esfuerza (t. medio) hacia él (complemento)».

El tiempo pasivo es intransitivo («impetu facto irrumpo»). Tendría un doble sentido:

1.-El Reino de Dios «es forzado" o suprimido por los fariseos, que cierran la puerta al pueblo para que no pueda entar en él. (No aceptado por la tradición).

2.-El Reino "es forzado" por la multitud, que lo acepta y lo asalta con valentía. Violencia santa y laudable, porque es arrebatado superando obstáculos y dificultades virilmente. Esta segunda posibilidad es la defendida por Ambrosio, Jerónimo, Maldonado. Juan el Bautista es el gozne entre la vieja y nueva ley. Su predicación inaugura el nuevo Reino, y los violentos (decididos) se apresuran a conquistarlo, en cuanto siguen las indicaciones morales y aceptan a Jesús como el fundador de este nuevo Reino.

En esta segunda postura se halla también Cervantes, pues los apóstoles lo conquistaron con valentía: «a fuerza de brazos». Se une así nuestro escritor a la opinión común de su tiempo. 
Otras interpretaciones se han dado: la violencia desviada de los Zelotes que pretendían restablecer el Reino de Dios por las armas, o la de otros que opinan que el Reino de Dios se abre solo camino con violencia, es decir, con fuerza a despecho de todos los obstáculos ${ }^{11}$.

28. "Bendito sea Dios, que tal me ha dejado ver con mis propios ojos" (II,58).

Son palabras de Sancho que da gracias al cielo, pues en el encuentro de las imágenes no ha habido sobresaltos ni se ha echado mano a las armas como en otras aventuras. Por eso utiliza la frase del viejo Simeón cuando tomó en brazos al niño Jesús en el Templo:

«Benexit Deum et dixit: ...quia viderunt oculi mei salutare tuum» (Lc. 2,30). («Bendijo a Dios y dijo: ...porque han visto mis ojos tu salvación»).

Cervantes suprime "salvación» porque este no es el caso de la aventura, aunque, en cierto sentido, sea una salvación y liberación de aventuras con armas y descalabros.

29. «Y como un abismo llama a otro abismo y un pecado a otro pecado...n (II,60).

Vulgata: «abyssus abyssum invocat" (Ps. 41,8).

El «abismo" (en hebreo thom) es el mal universal que cubría la tierra entera (Gen. 1,2), antes que Dios separara las aguas del Océano en dos mitades. Desde entonces fue designada como «abyssusn la mitad inferior; sobre ella se apoya la tierra y de ella manan las fuentes y fluyen los ríos. En la Biblia el "tehom» no es una personificación como en Siria el «Tiamat", sino, a lo sumo, una personificación poética como en el salmo citado. En el N.T. indica también el lugar donde se encierran las fuerzas del mal y son castigados los demonios.

Cervantes aprovecha el texto para probar un segundo aforismo, también de origen bíblico: "Un pecado (llama) a otro pecado». El Libro del Eclesiástico escribe: "Neque ejicias peccatum super peccatum» $(5,5)$ : «No acumules pecado sobre pecado». El texto se repite en otro lugar: «Un mal llama a otro» $(\mathbf{I}, 28)$; fórmula común a otros refranes: «El dinero llama al dinero», etc. (ver refrán núm. 17 donde ofrezco más textos bíblicos).

11 Véase el comentario de Pirot-Clamer: La Sainte Bible, t. IX (S. Mathieu et S. Marc, p. 144), y la Biblia de Jerusalén, p. 1403, nota a Mt., 11,12. 
30. "Dio su espíritu" (II,74).

Cervantes relata la muerte de don Quijote en las últimas páginas de su libro. Después de haber recibido todos los sacramentos (confesión, extremaunción y eucaristía), y haber abominado de los libros de caballerías, entre compasiones y lágrimas de los asistentes, "dio su espíritu, quiero decir que se murió». Cervantes recoge la fórmula evangélica de la muerte de Jesús, aceptando la dicotomía de cuerpo-alma. "Dar el espíritu" es el modo más corriente de anunciar la muerte de alguien:

«Et inclinato capite, tradidit spiritum» $(\mathrm{Jn} .19,30): \propto E$ inclinada la cabeza, dio el espíritux.

31. "Es una guerra nuestra vida sobre la tierra" (La Galatea, lib. IV).

Es traducción literal de la Vulgata: «Militia est vita hominis super terram" (Job 7,1).

Esta imagen es muy tradicional y tópica, pero bien la pudo tomar directamente de la Biblia o de las predicaciones. Job vuelve a hablar de "los días de la milicia» $(14,14)$. La palabra indica el sentido de servicio militar, de lucha y servidumbre. El texto de los LXX escribe "prueba" en lugar de "milicia». Cervantes escribe "guerra", como algo unido siempre a la "milicia», que él conoció personalmente.

32. "No es bien echar las margaritas a los puercos" (El Coloquio de los Perros).

Vulgata: «Neque mittatis margaritas vestras ante porcos" (Mt. 7,6).

El aforismo lo dice Jesús en vistas a la profanación de las cosas santas: manjares sagrados, alimentos santificados por haber sido ofrecidos al Templo. Tampoco se puede proponer una doctrina santa a gente incapaz de recibirla bien. El texto no precisa de quién se trata, si de los judíos o de los paganos. En Lucas una pagana se considera "un perrito", que puede comer de las migajas que caen de la mesa de su amo (Lc. 15,26).

33. «Derribar los soberbios levantados / y alzar a los humildes abatidos" (El Coloquio de los Perros).

Rodríguez Marín y F. Maldonado de Guevara creen que Cervantes lo toma de la Eneida:

«parcere Subiectis et debellare superbos» (Lib. V, 354). 
Opino que el parecido es mayor con el Magnificat de María:

\author{
«Dispersit superbos cordis sui, \\ deposuit potentes de sede \\ et exaltavit humiles» (Lc. 1,51-52).
}

El mismo Cervantes da la significación, al repetir más abajo los mismos versos, tratando de la nueva forma que tomarán los perros:

"Cuando viéramos que los que ayer estaban en la cumbre de la rueda de la Fortuna, hoy están hollados y abatidos a los pies de la desgracia y tenidos en pocon.

De nuevo los compara con el juego de los bolos, donde se derriban los que están en pie, y se vuelven a alzar los caídos.

Esta idea es frecuente en la Biblia: Dios aborrece la soberbia y levanta a los humildes. Job se expresa así:

«Para poner en alto a los postrados,

y que los míseros a la salud se eleven» (Job 5,11; 12,19; Ps. 88,11, etc.)

34. "¿No sabes que el mismo Cristo dijo: / "Aquel que me negare ante los hombres, / de mí será negado ante mi Padre; / y el que ante ellos a mí confesare, / será de mí ayudado ante el Eterno / Padre mío... (El Trato de Argel, jorn. IV).

El texto no es exactamente literal porque Cervantes debe acomodarse a las necesidades de la versificación. Pero, de todas maneras suena igual que el Evangelio:

"Todo aquel que me confiese ante los hombres, lo confesaré yo ante Padre que está en los cielos; pero a quien me negare ante los hombres, le negaré yo también ante mi Padre que está en los cielos» (Mt. 10,32-33).

Son las palabras de un tal Saavedra, que invierte los términos evangélicos: primero la negación y después la confesión. Saavedra (que no es otro que Cervantes) se dirige a Pedro que muestra deseos de renegar de la fe públicamente, haciéndose moro en apariencia, para ganar la libertad. El texto cervantino se escribe en la misma situación vital del Evangelio: miedo a la persecución y a la muerte por Cristo.

En la misma comedia Hazan, moro convertido, alude a las negaciones de San Pedro Apóstol:

«uen Dios, perdona el exceso
de haber faltado en la fe,
pues, si en público te negue,
en público te confiesol» (jorn. I). 
Cervantes se muestra cristiano en esta obra, como pocas veces. Al mismo Pedro que desea fingir, le dice:

«Sea loado Jesucristo, amigo Pedro, ¿no sabéis cómo el martes es vigilia y que manda la Iglesia que ayunemos?» (jorn. IV).

35. «El corazón humillado, / Dios por jamás lo desprecia» (Rufián Dichoso).

El texto, que ya reproduje en latín (ver mi art. t. XXXI, p. 48), está tomado de un Salmo, donde en la Biblia es oración y en Cervantes afirmación: «No desprecies, oh Dios, un corazón contrito y humillado" (Ps. 50,19).

Este Salmo, tradicionalmente atribuido a David, se mueve en el círculo penitencial profético, sobre todo de Isaías y Ezequiel. Representa, según el título, el arrepentimiento de David por la corrección de Natán, a causa del asesinato de Urías y el adulterio con su mujer Betsabé, aunque el salmo no hace alusión a estos acontecimientos.

El texto tiene relación con lo que hemos dicho de los humildes (ver núm. 1 y 33 de estas citas castellanas). Al igual suenan las palabras del ladrón Roque Guinart a don Quijote:

«...el cielo, por extraños y nunca vistos deseos, de los hombres no imaginados, suele levantar a los caidos y enriquecer los pobres» $(\mathrm{II}, 60)$.

El Libro de los Proverbios insiste:

"Con los arrogantes es también arrogante, otorga su favor a los pobres» (Prov. 3,34).

\section{Y San Pedro comenta:}

«Dios resiste a los soberbios y da su gracia a los humildes» (I Pedr. 5,5).

36. "Que se regocijará en el cielo / quando una nueva conciencia / se vuelve a hacer penitencia / un pecador en el suelo" (Rufián Dichoso).

El texto suena así en la Vulgata:

«Dico vobis quod ita gaudium erit in caelo super uno peccatore poenitentiam agente...” (Lc. 15,7 y 10).

Cervantes añade «suelo" por razones de rima con «cielo». La alegría por un pecador que se convierte a Dios, es varias veces repetida. En la misma comedia se escribe: 
«Cuando un pecador se vuelve

a Dios con humilde celo

se hacen fiestas en el cielon

En una poesía suelta dedicada a la toma de hábito de Fray Pedro de Padilla:

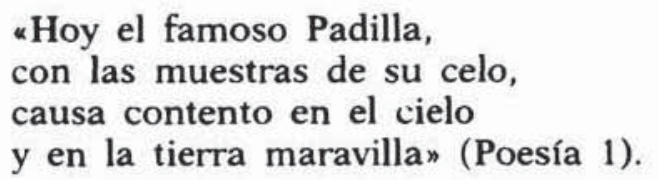

37. "Crió Dios la medicina y ha de tenerse en precio" (Rufián Dichoso).

Es parte del texto del Eclesiástico citado por el Licenciado Vidriera en latín (ver mi art. t. XXXI, p. 44). Cervantes traduce el texto literalmente de la Vulgata:

«Altissimus creavit nedicinam, et vir prudens non abhorrebit illa».

El texto y la cita completa señalada, difícilmente se oyen en una predicación popular, por lo que se supone que Cervantes leía la Biblia.

38. «No quiere Dios del pecador más malo, sino que viva y se arrepienta» (Los Alcaldes de Daganzo).

La Vulgata escribe:

«Dicit Dominus Deus: "Nolo mortem impii, sed ut convertatur impius a via sua, et vivat” (Ez. 33,11). ( NNo quiero la muerte del impío, sino que se convierta de su conducta y vivax).

Esta idea sobre la voluntad divina hacia los pecadores es muy corriente en la Biblia (Sab. 1,13; Jer. 15,19; Ez. 18,23.32; Zac. 1,3; 10,6; Mt. 9,13; Mc. 2,17; Lc. 15,1; I Tim. 2,4, etc.).

39. «Si no estuviere enseñado en la verdad católica, y me acordara de lo que dice Dios en el Levítico: "No seáis agoreros, ni deis crédito a los sueños, porque no a todos es dado entenderlos" " (Los Trabajos de Persiles y Segismunda, I, XVIII).

Vulgata: "Non augurabimini, neque observabitis somnia" (Lev. 19,26).

En la misma obra póstuma de Cervantes, el bárbaro italiano Rutilio, habla sobre las hechiceras que se convierten en lobos: 
«Cómo esto puede ser, yo lo ignoro, y como cristiano que soy católico, no lo creo... Lo que puedo alcanzar es que todas estas transfiguraciones son ilusiones del demonio y permisión de Dios y castigo de los abominables pecados de este maldito género humanon (Lib. I, cap. VII).

Cervantes se siente contrario hacia tales "agüeros». Un demonio se dirige a Fátima, que quiere hechizar a Anselmo para atraerlo a su amor. El demonio dice:

«Todos los aparejos son en vano, porque un pecho cristiano, que se arrima a Cristo, en poco estima hechicerías» (El Trato de Argel, j. II).

Don Quijote tuvo por buen «agüero» el haberse topado con las imágenes de los santos. El caballero responde a Sancho sobre este buen suceso:

«Esto que el vulgo suele llamar comúnmente agüeros, que no se fundan en sobrenatural razón alguna...» (II,58).

En el mismo capítulo don Quijote describe algunos de estas supersticiones: algunos, al ver un fraile franciscano, vuelven la espalda y corren a sus casas; otros creen que el derramar la sal sobre la mesa es signo de futuras desgracias, etc. En resumen, concluye el caballero:

"El discreto y cristiano no ha de andar en puntillas con lo que quiere hacer el Cielo" (II,58).

La Biblia prohíbe los agüeros en varios lugares (Ex. 22,18; Lev. 20,6.27; Dt. 18,10-14; Jer. 29,8, etc.).

40. «Porque en cualquier tiempo es mejor casarse que abrasarse” (Persiles, II,XVIII).

Vulgata: "Melius est enim nubere, quam uri» (I Cor. 7,9). Este dicho de San Pablo aparece también en los refraneros españoles (lo tratamos en el refrán núm. 18 de mi art. t. XXVII, p. 58).

El dicho lo repite en El viejo celoso, indicando su autor:

«Error fue ese, pero no muy grande; porque según el dicho del Apóstol mejor es casarse que abrasarse».

41. "Los cielos y la tierra anunciaban y declaraban las grandezas del Señor» (Persiles, III,XI).

Los autores b́blicos repiten miles de veces la creación de cielos y tierra por parte de Dios, con poder y fuerza (Jer. 32,17). Su ma- 
jestad es celebrada desde el fondo del mar (Is, 24,14). Por eso se invita a hombres y elementos creados a que alaben su grandez y su poder:

«Los cielos anuncian la gloria de Dios» (S. 19,2).

«Alábenlo cielos y tierra» (S. 68,35).

«Los cielos celebran, Yahveh, tus maravillas» (S. 89,6).

«Alabadle por su inmensa grandeza» (S. 150,2. Ver S. 69,22; 147, 148,1-7; 96,6; Habac. 3,3; Ecclo. 17,7-8, etc., etc.).

42. «El amor viene a ser poderoso como la muerte» (Persiles, I,XXIII).

Es la traducción literal de la Vulgata:

«Quia fortis est ut mors dilectio» (Cant. 8,6).

Cervantes utiliza la única definición del amor que hay en el Cantar de los Cantares, poema íntegramente amoroso. Cervantes trató del amor en todas sus obras como pocos autores del Barroco. El término "fuerte" lo toma de la Vulgata, mientras el texto hebreo (ázzâh) habría que traducirlo por "insaciable». La novia expresa con fuertes y bellos términos el poder invencible del amor, que se compara con la "Sabiduría": "Los que me comen quedan aún con hambre de mí, los que me beben sienten todavía sed" (Ecclo. 24,21; Vg. 24,29).

En la Galatea repite el texto: "Hará fama creíble, / que el amor es poderoso / y la muerte invencible» (Lib. V).

43. "Lo que escribí, escribín (Pedro de Urdemals, Jorn. I).

Transcripción de las palabras de Pilato, cuando los judíos le aconsejaron que no escribiera sobre la cruz: «Jesús, Rey de los judíos». Pilato respondió: «quod scripsi, scripsi" (Jn. 19,22: "Lo que escribi, escribi"). En la obra cervantina, lo dice un alcalde al firmar una sentencia.

\section{CONCLUSION}

Todos los textos señalados son citas literales en castellano, que algunas veces pueden venir de oídas en sermones o en la liturgia, pero no siempre. Cervantes pudo utilizar alguna Biblia romanceada de la Vulgata. El P. Llamas, que ha estudiado las Biblias de El Escorial, habla de una Biblia prealfonsina y otra que utilizó el rey 
Sabio para su General Estoria, ciertamente vertida de la Vulgata, según asegura este autor. Muchas Biblias escurialenses proceden de la Vulgata ${ }^{12}$. A esta misma conclusión, sobre la Vulgata de Alfonso X, llegan Hauptman y Menéndez Peláez ${ }^{13}$. Los Reyes Católicos promovieron también las Biblias en romance, pero ellos se dedicaban más bien al expurgo de algunas sospechosas, como lo demuestra la quema de sólo veinte ejemplares en Salamanca (25-Sept.1492). Por otro lado se sabe de innumerables Biblias en el s. XVI, de modo total o parcial. Como he demostrado en los artículos míos (nota 1), Cervantes utilizó Biblias anteriores al Concilio de Trento, impresas en Lyon. Otros tradujeron Salmos, epístolas de San Pablo, Evangelios, etc. procedentes todos de la Vulgata. El mismo Lope de Vega escribe:

«En mi tiempo había [Biblias] en romance, y estuvo bien quitada y con santo acuerdo, porque somos muy bachilleras las mujeres y no hay pocos ignorantes hombres» (La Dorotea, II,4).

No creemos que usara las versiones protestantes de Casiodoro de la Reina y Cipriano de Valera, coetáneas de Cervantes, pues se publicaron en el extranjero e iban contra la prohibición de Trento.

De cualquier manera, Cervantes debió usar una Biblia latina (para los textos latinos, como ya demostré) y otra en castellano procedente de la Vulgata.

\section{CELSO BAÑEZA ROMÁN}

12 P. Llamas: Bliblias Medievales Romanceadas, Madrid, CSIC, 1952, p. 17.

13 O. R. HAUTPTMAN, *The General Estoria of Alfonso X el Sabio and Escorial Biblical Manuscript I-j-8», en $H R$, XIV, 1945, pp. 45-59. Del mismo autor: Escorial Bible I-j-4, vol. I: The Pentateuch, Filadelfia, 1953.

J. Menéndez Peláez, «La Biblia romanceada y su influencia en la General Estoria», en Estudio Ovetense, V, 1977, pp. 37-65. 